\title{
УДК 796.01
}

DOI: $10.15587 / 2519-4984.2020 .192832$

\section{РОЗВИТОК ПІСЛЯДИПЛОМНОЇ ПЕДАГОГІЧНОЇ ОСВІТИ БУКОВИНИ ПЕРШОЇ ПОЛОВИНИ ХХ ст.}

\section{О. О. Цибанюк}

Потреба у фахових кадрах на теренах Буковини з'явилась безпосередньо в момент становлення системи фізичного виховання школярів краю середини XIX cm. В змісті «Організаційного нарису гімназій та реальних шкіл в Австро-Угорський імперії», закону від 14 травня 1869 р. з’явилось офіційне визнання «тілесних вправ» як обов'язкового предмета викладання. Крім того, вагому роль в кадровому забезпеченні системи фізичного виховання Буковини відігравало розпорядження міністра віросповідань та освіти щзодо вимог про порядок прийняття державних екзаменів у кандидатів на здобуття посади вчителя гімнастики (1870).

Саме нестача професійних кадрів змусила громадських активістів організовувати різноманітні форми підготовки вчителів гімнастики, інструкторів з загальної фізичної підготовки, пожежно-січової справи. В столиці краю систематично проводили «гімнастично-пожарничі» курси, в популяризації яких активно приймала участь буковинська преса. На вимогу системи фізичного виховання всіх верств населення Буковини в краї була створена процедура підготовки та підвищення кваліфікації фахівців цієї галузі. Але об'єднати всі форми підвищення кваліфікації в єдину держсавну систему, сформувати заклад, шсо відповідав вимогам часу, педагогічним положенням стало можливим лише в 40-рр. ХХ ст. Період 1938 1939 рр. став етапом становлення системи методичної роботи з керівними та педагогічними кадрами освіти УРСР. Основними складовими иієї діяльності стали: школа, кущові методичні об'єднання, педагогічні кабінети при районних відділах народної освіти, інститути удосконалення вчителів при обласних відділах народної освіти.

Основними формами післядипломної педагогічної освіти було визначено такі: курсові заходи підвищення кваліфікації; семінари і педагогічні практикуми; радіо лекиії; конференції, гуртки, наради і виставки $з$ питань обміну кращим педагогічним досвідом; загально-освітні та спеціальні навчальні екскурсї; систематичні консультації та інструктажі; розповсюдження методичних матеріалів (стенограм уроків, методичних розробок, збірників); проведення науково-дослідної роботи з класом; співпраця кращих учителів із кафедрами вищих навчальних закладів і науково-дослідних установ.

Інститут складався з дев'яти навчально-методичних кабінетів, зокрема: педагогіки, початкових класів, украӥнської і російської мови та літератури, іноземних мов, історії та географії, математики і фізики, біології й хімії, фізичної культури, позашкільного виховання

Ключові слова: Буковина, курси, навчальні предмети, слухачі, фахівці, фізичне виховання, форми роботи

Copyright (C) 2020, O. Tsybaniuk. This is an open access article under the CC BY license (http://creativecommons.org/licenses/by/4.0).

\section{1. Вступ}

Сучасний світ вимагає від системи освіти миттєвого реагування на запити соціуму. Саме напрями реформування сучасної освіти визначають стратегію розвитку вітчизняної освіти на десятиліття. Важливого значення набуває в цьому процесі оптимізація всіх рівнів вітчизняної освіти, зокрема післядипломної педагогічної освіти - «освіти протягом життя», яка визначає шляхи підготовки сучасного фахівця щодо впровадження нового змісту освіти на основі нових освітніх програм та державних стандартів. Історія розвитку підготовки вчителів для викладання предмета «фізична культура» на Буковині - не досліджена проблема, у якій ще не розкрито багато важливих питань.

Унаслідок історичних обставин цей регіон протягом довгого часу входив до різних держав, реалізовував різні освітні ідеології, тут по різному реалізовували освітні завдання.
2. Аналіз останніх досліджень і публікацій.

Загальні проблеми післядипломної педагогічної освіти визначені актуальними і були розглянуті в низці досліджень сучасних українських науковців. Темами для них стали сучасні проблеми та перспективи розвитку післядипломної педагогічної освіти, основні напрями цієї діяльності, які варто реструктурувати або оптимізувати $[1,2]$. Концептуальні положення організації та розвитку системи післядипломної педагогічної освіти в сучасному світі, очікувані результати слухачів курсів підвищення кваліфікації та інших форм освіти протягом життя викликають зацікавлення науковців і практиків [3].

Питання професійної підготовки вчителя та сучасні тенденції розвитку саме мистецької освіти стали предметом дослідження численних публікацій $[4,5]$. А теоретичний і методичний аспекти професійного навчання майбутнього педагога, зокрема роль мистецтва у системі розвитку творчої індивіду- 
альності висвітлені у монографіях та наукових статтях $[6,7]$.

Сучасна формація освіти дорослих, що не функціонує як самостійна сфера освітніх послуг, але представлена і взаємопов'язана 3 післядипломною освітою. В цьому контексті важливими стають питання підвищення кваліфікації та перепідготовки, аспірантури, докторантури тощо, ii історикопедагогічні аспекти та генеза розвитку, зокрема в західноукраїнському регіоні в різні історичні періоди $[8,9]$. В цьому контексті висвітлені питання освіти дорослих у педагогічній думці Австрії [10]. Проявляється сучасна тенденція наукового аналізу і порівняння аспектів безперервної освіти в різні історичні періоди в європейських країнах, основною тезою досліджень визначені якість освіти дорослих, рекомендації щодо іiі підвищення $[11,12]$. В науковий обіг введені складові системи фізичного виховання буковинського краю австро-угорського періоду, зокрема різноманітні форми підготовки фахівців цієї сфери, що використовувались педагогами, громадськими діячами, військовими в II половині XIX - початку XX ст. [13]. Особливої уваги дослідники приділили проблемам післядипломної педагогічної освіти Буковини у напрямі «фізичне виховання», підготовки кадрів галузі фізичної культури і спорту в краї історичному контексті $[14,15]$.

Аналіз вищезазначених наукових здобутків дозволили визначити вагомість історичного досвіду становлення і розвитку післядипломної освіти, зокрема в галузі фізичної культури і спорту та виокремити концептуальні засади, методологічні підходи в цьому напряму, проаналізувати сучасний стан розвитку науково-методичного супроводу підвищення кваліфікації вчителів. Варто звернути особливу увагу на те, що більш глибокого аналізу потребують питання використання досвіду післядипломної освіти регіону задля оновлення змісту післядипломної освіти, сучасні тенденції розвитку курсової підготовки фахівців сфери фізичного виховання на засадах освітніх реформ.

\section{3. Мета та задачі дослідження}

Мета статті: здійснити аналіз розвитку післядипломної педагогічної освіти Буковини в контексті підготовки кадрів галузі фізичного виховання першої половини XX ст.

Для досягнення мети були поставлені наступні завдання:

- виокремити історичні передумови формування системи післядипломної педагогічної освіти Буковини;

- проаналізувати процес становлення єдиної державної державної системи підготовки та підвищення кваліфікації педагогічних фахівців;

- визначити проблеми становлення діяльності інституту підвищення кваліфікації досліджуваного періоду.

\section{4. Матеріали та методи дослідження}

У відповідності до мети і завдань дослідження були використані два основних методи аналізу документів: порівняльно-аналітичний, формалізований (кількісний). Перший передбачав ретроспективний аналіз нормативно-правових документів, матеріалів періодичної преси для визначення змісту, форм та методів післядипломної педагогічної освіти Буковини досліджуваного періоду; порівняльний аналіз наукових статей, теоретичних та практичних наробок; предметно-цільовий аналіз першоджерел, матеріалів періодичних видань досліджуваного періоду. Задля виконання завдань дослідження нами були проаналізовані результати 2 дисертацій на здобуття наукового звання кандидат педагогічних наук, 2 пам'ятних книг виданих 3 нагоди 50-ліття та 75-ліття від часу заснування інституту післядипломної педагогічної освіти Чернівецької області, статей періодичних видань Буковини кінця XIX - початку XX ст.: «Народна справа» $\mathrm{i}$ «Громадянин». В статі використані матеріали наукових статей сучасних дослідників історії, проблем та перспектив розвитку післядипломної педагогічної освіти краю.

\section{5. Результати дослідження та їх обговорення}

Потреба у фахових кадрах на теренах Буковини з'явилась безпосередньо в момент становлення системи фізичного виховання школярів краю середині XIX ст. На розвиток цієї системи позитивно впливали декілька причин. Зокрема, до них відносимо формування законодавства Австро-Угорської імперії щодо освіти: «Організаційний нарис гімназій та реальних шкіл в Австро-Угорський імперії», закон від 14 травня 1869 р., розпорядження щодо вимог про порядок прийняття державних екзаменів у кандидатів на здобуття посади вчителя гімнастики від 1870 р. [13]. Однією із вагомих причин, що позитивно впливали на цей процес виокремлено формування освітнього законодавства Австро-Угорської імперії щодо народних шкіл та закладів середньої освіти: «Організаційний нарис гімназій та реальних шкіл в АвстроУгорський імперії», закон від 14 травня 1869 р. У змісті цих нормативно-правових актів з'явилось офіційне визнання «тілесних вправ» як обов'язкового предмета викладання [13].

Крім того, вагому роль в кадровому забезпеченні системи фізичного виховання Буковини відігравало розпорядження міністра віросповідань та освіти щодо вимог про порядок прийняття державних екзаменів у кандидатів на здобуття посади вчителя гімнастики (1870) [13].

Громадських рух, що активно розвивався в краї також потребував професійних кадрів. Саме їх нестача змусила громадських активістів організовувати різноманітні форми підготовки вчителів гімнастики, інструкторів з загальної фізичної підготовки, пожежно-січової справи. В столиці краю систематично проводили «гімнастично-пожарничі» курси, в популяризації яких активно приймала участь буковинська преса. 22-23 номер за 1908 р. «Народної справи» активно аналізував зміст курсів, що відбулися в Чернівцях 19-22 грудня того ж року. У практичних та лекційних заняттях приймало участь 80 курсантів 3 40 буковинських осередків. Серед інструкторіввикладачів виділявся Довганюк з Сопова який давав практичний клас 3 шикувань та перешикувань, подолання перешкод різними способами та класичної гім- 
настики. Його практичне заняття було поділене на 3 великі частини і тривало 6 годин. Автор звіту, що залишився невідомим, зазначав, що після першого дня курсів учасники висловили свою думку про успішність саме такої форми роботи і на наступний день прийшлось винаймати інше приміщення, адже старе не вміщувало всіх бажаючих. Серед теоретичних форм виділялись лекція Г. Герасимовича про січові справи, бесіда доктора Бурачинського про першу допомогу при нещасних випадках та Д. Кузика «про спілкову справу». Запланована екскурсія на чернівецьку пожежну станцію отримала тільки позитивні відгуки і заставила «подумати інших» [16].

Громадськість і преса широко розповсюджували інформацію про такі форми підвищення кваліфікації. Номери буковинських газет прослідковували зріст зацікавлення такими курсами, зафіксувавши кількість слухачів на них, наводили перелік практичних занять, тем лекцій, їх тривалість, прізвища інструкторів та лекторів тощо [16].

Метою суто «січового підготовчого курсу» (19-23 грудня 1908 р.) став обмін досвідом щодо оптимізації роботи вже 3 наявним членами та пропаганді січового руху задля їх збільшення. В курсі прийняли участь 39 осередків 3 усіх повітів Буковини, всього 54 делегати [17]. В програму входили просвітницькі бесіди на різноманітні теми: «Як проводити загальні збори?», «Стан касовий», «Тілесні вправи: як і що робити!», «Прибори для «Січи» [18]

Курси, організовані у січні 1909 року, викликали зацікавлення в краї, про що свідчили відгуки слухачів, надруковані на сторінках «Громадянина». Тому, виконуючи прохання та звернення січовиків, 3-5 грудня 190 року на сторінках газети було оголошено про проведення II курсу пожарногімнастичного за такою програмою: «3 і 4 грудня. Рано - гімнастичні вправи. По полудню - пожарничі вправи. Вечір - відчити 1) про діловодство; 2) про як Сїч має жити і що робити? 3) про горівку; 4) про товаришів; 5) про рятунок при пожарі» [19].

5 грудня відбувся урочистий збір учасників із видачею свідоцтв про проходження курсів, обговорення змісту та результатів навчання, визначення недоліків та перспектив. Важливо, що участь хоча б одного представника кожної буковинської «Січі» була обов'язковою.

На вимогу системи фізичного виховання всіх верств населення Буковини в краї була створена процедура підготовки та підвищення кваліфікації фахівців цієї галузі. Але об'єднати всі форми підвищення кваліфікації в єдину державну систему, сформувати заклад, що відповідав вимогам часу, педагогічним положенням стало можливим лише в 40-pp. ХХ ст. Період 1938-1939 рр. став етапом становлення системи методичної роботи з керівними та педагогічними кадрами освіти УРСР. Основними складовими цієї стали: школа, кущові методичні об'єднання, педагогічні кабінети при районних відділах народної освіти, інститути удосконалення вчителів при обласних відділах народної освіти.

Після возз'єднання Буковини з іншими етнічними українськими землями у складі УРСР освітня діяльність здійснювалась відповідно наказів і розпоряджень Народного комісаріату освіти. Відповідно до наказу Наркома освіти від 21 лютого 1939 року № 1203, інститути післядипломної педагогічної освіти здійснювали свою діяльність згідно із нормативноправовими актами, що регламентували роботу системи освіти, та Положенням про «Обласний інститут удосконалення учителів Української РСР».

Основними формами післядипломної педагогічної освіти було визначено такі: курсові заходи підвищення кваліфікації; семінари і педагогічні практикуми; радіо лекції; конференції, гуртки, наради і виставки $з$ питань обміну кращим педагогічним досвідом; загально-освітні та спеціальні навчальні екскурсії; систематичні консультації та інструктажі; розповсюдження методичних матеріалів (стенограм уроків, методичних розробок, збірників); проведення науково-дослідної роботи 3 класом; співпраця кращих учителів із кафедрами вищих навчальних закладів і науково-дослідних установ [20].

3 метою оптимізації післядипломної педагогічної освіти за постановою Уряду та наказу Міністерства освіти від 28.08. 1940 р. розпочав свою роботу новий структурний підрозділ - Обласний інститут удосконалення кваліфікації вчителів. Першим директором Інституту було призначено Котка П. А.

Інститут складався 3 дев'яти навчальнометодичних кабінетів, зокрема: педагогіки, початкових класів, української і російської мови та літератури, іноземних мов, історії та географії, математики і фізики, біології й хімії, фізичної культури, позашкільного виховання. Також працювали бібліотекар, завгосп, бухгалтер, прибиральниці. Всього штат інституту налічував близько 20 осіб.

У 1940-1941 н. р. у школах Чернівецької області навчалося 108 тис. 950 дітей. Окрім загальноосвітніх шкіл, в області було створено 2 педагогічні школи, які готували учителів для 1-4 класів. У 380 школах регіону проводили навчання 3 неписьменними і малописьменними людьми. Для перепідготовки педагогічних кадрів улітку 1940 року було організовано короткострокові курси. На них навчалося близько 2000 осіб. Крім цього, зі східних областей України на Буковину на постійне місце роботи приїхало 1180 учителів [9].

Потужними темпами Інститут удосконалення вчителів організовував десятиденні курси перепідготовки з числа безробітних учителів, випускників гімназій, учительських семінарій, університету. Майбутніх педагогів знайомили з організацією та системою роботи в радянських школах, 3 методами навчання та виховання.

Радянська система освіти взагалі передбачала підвищення професійного рівня учителя шляхом ознайомлення 3 новими досягненнями педагогічної науки, кращим педагогічним досвідом та результатами психолого-педагогічних досліджень у період проведення курсової перепідготовки [20].

За місяць навчання курсову перепідготовку пройшли 1200 осіб. Крім того, окремо організували курси для 12 шкільних інспекторів районних відділів народної освіти та курси завідувачів початкових шкіл. 
Одразу появились перші проблеми. Відповідно до положення народного комісаріату у всіх районах області були відкриті районні педагогічні кабінети та організували 83 «методичні кущі». А в румуномовному Герцаївському районі не знайшлося фахівця, який міг би очолити такий кабінет.

Станом на 16 вересня 1940 р. для старших класів не вистачало програм 3 математики та історії. В україномовних школах справа 3 підручниками була вирішена, але школи 3 румунською мовою навчання зовсім не були забезпечені підручниками. Не вистачало й учителів. Для вирішення цієї проблеми в школи Чернівецької області направили близько 100 педагогів зі східних та південних районів України, які за прискореною програмою закінчили навчання в педагогічних школах і мали забезпечити навчальновиховний процес на Буковині.

Надаючи методичну допомогу, готуючи до екзаменів, працівники Інституту виконували ще пропагандиську роботу: проводили перепис населення, створювали піонерські та комсомольські організації, розповсюджували книги, брали участь у різноманітних заходах.

3 початком Великої Вітчизняної війни Інститут у липня 1941 р. припинив свою діяльність. Директора і переважну більшість педагогічних працівників було евакуйовано на схід, а частину працівників мобілізовано до армії.

У березні-квітні 1944 року буковинську землю було звільнено від окупації. Одразу відновлює свою роботу Обласний інститут удосконалення кваліфікації вчителів. Згідно з наказом Обласного відділу освіти від 16 квітня 1944 року, директором інституту було призначено П.Д. Онищенка, через тиждень видано накази на прийом на роботу бібліотекаря Д. Г. Алтной, бухгалтера М.А. Айнгорна, завгоспа В. Г. Лебля. Міська рада задля ефективної діяльності відвела будинок-палац по вулиці генерала Мірческу, 25 (на даний час - Шептицького).

У травні колектив поповнився науковими співробітниками: М. І. Грищенко (природничі науки), Ф. М. Гутман (іноземні мови), Л. Д. Руденко (початкові класи). Восени Обласний відділ народної освіти призначив завідувачів методичних кабінетів: початкових класів - Г. А. Малевич, мови А. М. Косань, історії та географії - А. М. Батмана, біології та хімії М. І. Грищенко.

Завідувачем кабінету педагогіки було призначено О.П. Новицького, людину великої освіченості, високої культури, величезного досвіду роботи в школі. Методисти кабінету педагогіки працювали над загально-педагогічними проблемами з працівниками районних відділів освіти, директорами та завучами шкіл. У 1954 році йому першому в області було присвоєно звання заслуженого вчителя УРСР.

3 перших днів своєї діяльності завідувачі кабінетів інституту широко залучали до роботи над підвищенням кваліфікації вчителів шкіл області наукових працівників університету, вчительського і педагогічного інститутів, викладачів педагогічного училища, працівників партійних органів, які читали лекції відповідно до програми Міністерства освіти.
Особливо тісними були наукові зв'язки 3 кафедрою педагогіки Чернівецького державного університету під керівництвом I. I. Кобиляцького.

3 вересня 1944 року працівники Інституту почали надавати консультації вчителям. Кожну консультацію фахівця чітко реєстрували у відповідному журналі, про що консультований отримував розписку.

Незважаючи на те, що військові дії продовжувались, інститут розпочав підготовку до проведення курсів у місті Чернівцях та у районних центрах. Так, 21 липня 1944 року розпочали свою роботу курси для учителів початкових шкіл, адже їх серед навчальних закладів області було найбільше.

Проблем було чимало. Насамперед не вистачало кваліфікованих педагогів. Завідувачі кабінетів запрошували на роботу у школу всіх тих, хто мав курс навіть незакінченої австрійської чи румунської гімназії, пропонуючи подальше навчання у педагогічному училищі або учительському інституті.

Не вистачало паперу і тому використовували недописані аркуші паперу різних канцелярських установ часів румунської окупації. Відсутність житла та проблеми із харчуванням для сільських учителів у райцентрах вирішувалась в робочому порядку.

Відповідно до програм Міністерства освіти України, навчальний план курсів було розраховано на 167 годин. Після завершення місячного навчання слухачі складали заліки та екзамени з предметів навчального плану. Навчання було організовано у дві зміни: 38 години ранку до 8 години вечора на базі середніх шкіл № 2, 9 та фізико-математичного корпусу Чернівецького університету. До послуг курсантів була інститутська бібліотека.

Слухачів, які пропускали заняття на курсах без поважних причин, відраховували, що відображали у відповідному наказі, який відправляли на управління освіти того району, звідки був курсант.

За роботу курсів відповідав завідувач кабінету, який вже на початку вересня їздив у райони i складав списки майбутніх слухачів курсів. Якщо таких не вистачало, звертався у районні та міські школи до тих, хто ще не проходив курсову перепідготовку. Все це робили для того, щоб виконати план. Адже саме у повоєнний період така проблема виникала досить часто, бо чимало педагогів навчалися заочно. Завідувач знаходив готель для слухачів, продумував для них програму відпочинку: походи в театр, кіно чи музей.

Кожен співробітник з 21 липня по 1 серпня читав лекції за своїм фахом, зокрема: з основ педагогіки, методики історії, географії, природознавства, каліграфії. Проте кількість годин, витрачену на це, не зараховували в робочий день і компенсували роботою після 18 години.

Співробітники інституту, прочитавши лекції на міських курсах, їхали до райцентрів. На кожного припадало по 3 або й 4 райцентри. Одного дня курсанти слухали лекції з каліграфії, наступного - 3 історії, потім - $з$ географії, природознавства, арифметики та інших предметів, залежно від того, ким за фахом був лектор.

Кожного співробітника відправляли у відрядження для підготовки до січневих конференцій те- 
рміном на 9 днів 3 метою вивчення стану справ того чи іншого району. Після повернення з відрядження працівники готували довідку про виконану роботу, вказуючи на позитивне чи негативне і зазначаючи форми і напрями наданої методичної допомоги у перевірених закладах. Окрім цього, доводилось працювати й у вихідні дні, під час яких науковці читали лекції про повторення навчального матеріалу та підготовку учнів випускних класів до екзаменів.

За невиконання розпорядження директора $\mathrm{IH}_{-}$ ституту щодо трудової дисципліни співробітників могли притягнути до карної відповідальності, відповідно до наказу від 8 вересня 1944 року.

Особливо важким було становище у румуномовних школах Герцаївського та Глибоцького районів. Переважна більшість учнів не володіла українською мовою. Саме в школи цих районів методисти виїжджали найчастіше, і це поступово почало приносити відчутні результати. Інспектори не лише особисто проводили уроки, але й залучали до цього досвідчених учителів. На базі кращих шкіл проводили міжрайонні семінари [19].

У перше повоєнне десятиріччя відрядження тривали від трьох днів до двох тижнів. Усе залежало від стану справ у районі, починаючи 3 навчальновиховного процесу у дитячих колгоспних майданчиках, дитячих будинках, садках, будинках піонерів, закінчуючи денними (часто у дві зміни) та вечірніми школами.

Під час проведення курсів завідувачам кабінетів доводилося працювати навіть у неділю. Цей день вони використовували для того, щоб спланувати різні види дозвілля для слухачів курсів, зокрема: культпоходи у кіно, театр, музеї, філармонію. Найпоширенішою формою відпочинку було обговорення книг.

Якщо співробітники Інституту мали години у міських школах, технікумах, учительському інституті чи університеті, то вони відпрацьовували свої основні робочі години у вечірній час: з 18.00 до 21.00.

Категорично заборонялося відлучення з Інституту хоча б на одну годину без погодження з адміністрацією. Присутність чи відсутність працівників на робочому місці обов'язково фіксували у реєстраційній книзі, вказуючи причину. Якщо відповідного запису не було, то це вважалося прогулом. Запізнюючись на роботу навіть на 5 хвилин, співробітники Інституту отримували зауваження від директора.

Щосуботи з 16 до 18 години директор проводив наради, де працівники інституту доповідали про виконану роботу. Найбільшу увагу звертали на виявлені недоліки.

У 50-х роках почали проводити обласні педагогічні читання, куди запрошували кращих педагогів 3 метою обговорення проблемних та актуальних питань щодо навчально-виховного процесу. Тематику виступів розробляли в Інституті, дотримуючись рекомендацій Українського науково-дослідного інституту педагогіки та Академії педагогічних наук УРСР. Зазвичай читання проводили під час березневих канікул, щоб не зривати навчальний процес. Кращим педагогам області через районні відділи освіти пропонували теми виступів, що залежали від питань, які мали б обговорювати під час читань. Учитель готував виступ кілька місяців. Методисти, завідувачі кабінетами приїжджали в школу, перевіряли стан підготовки написаного, вносячи відповідні корективи. Обов'язково у виступі мали звучати цитати 3 праць Сталіна, Леніна, керівників Комуністичної партії, рішень партійних з'їздів, а також видатних педагогів Н. Крупської, К. Ушинського, А. Макаренка та інших. Крім того, зі шкіл збирали експонати для виставки, виготовлені руками учнів під керівництвом учителів біології, історії, фізики, трудового навчання. I для учителя, і для директора школи, і для завідувача районного відділу освіти це було нелегкою і відповідальною справою [20].

\section{6. Висновки}

1) особливостями післядипломної педагогічної освіти Буковини в галузі фізичного виховання першої половини XX ст. стали сформована потреба у висококваліфікованих кадрах як для системи освіти, так i для громадських організацій фізкультурноспортивної спрямованості, що діяли на теренах краю.

2) Крім того, була створена потужна система законодавчого регламентування підготовки фахівців галузі фізичної культури і спорту, зокрема вчителів гімнастики. Але об'єднання всіх форм підвищення кваліфікації в єдину державну систему, оформлення дотичного закладу та систематична діяльність стали можливими лише в 40-их рр. ХХ ст.

3) До проблем становлення діяльності інституту підвищення кваліфікації досліджуваного періоду відносимо відсутність фахівців, що на достатньому рівні володіли регіональними мовами; брак навчальних програм, методичних посібників і підручників; незадовільні умови проживання і навчання працівників інституту і слухачів курсів тощо.

\section{Література}

1. Олійник В. В. Сьогодення та перспективи розвитку післядипломної педагогічної освіти // Постметодика. 2012. № 4 (107). C. 2-6.

2. Сущенко Т. І. Концепція розвитку післядипломної педагогічної освіти // Післядипломна освіта в Україні. 2007. № 1. C. $23-27$.

3. Устинова Н. В. Розвиток творчого потенціалу вчителя у системі післядипломної освіти: автореф. дис. ... канд. пед. наук. Київ, 2006. 24 с.

4. Козир А. В. Основні тенденції розвитку мистецької освіти на сучасному етапі // Професіоналізм педагога: теоретичні й методичні аспекти. 2016. № 3. С. 25-37.

5. Кузнецова В. М., Шеверницька Н. М. Сучасні тенденції мистецької освіти // Мистецька освіта. Вісник ХДАДМ. 2017. № 3. C. 15-19.

6. Лавринець А. П. Сучасні тенденції мистецької післядипломної педагогічної освіти // ScienceRise: Pedagogical Education. 2018. № 4 (24). C. 47-50. doi: http://doi.org/10.15587/2519-4984.2018.132657 
7. Отич О. М. Мистецтво у системі розвитку творчої індивідуальності майбутнього педагога професійного навчання: теоретичний і методичний аспекти: монографія. Чернівці: Зелена Буковина, 2009. 752 с.

8. Рудницька О. П. Педагогіка: загальна та мистецька: навч. пос. Київ, 2002. 270 с.

9. Осколов П. В., Федоряк В. Ф., Черкач Н. І. Короткий нарис історії Чернівецького обласного інституту післядипломної освіти (до 65-річчя). Чернівці: Технодрук, 2005. 62 с.

10. Боярська-Хоменко А. Розвиток питань освіти дорослих у педагогічній думці Австрії // Педагогічні науки. 2019. № 86. C. 18-22.

11. Тимчук Л. І. Система освіти дорослих в Україні (50-80-ті роки ХХ ст.) // Освіта дорослих: теорія, досвід, перспективи. 2015. № 1 (10). С. 123-134.

12. Egetenmeyer R. Adult Education and Lifelong Learning in Europe and Beyond. Comparative Perspectives from the 2015 Würzburg Winter School. Frankfurt am Main, Berlin, Bern, Bruxelles, New York, Oxford, Wien, 2016.276 p. doi: http://doi.org/10.3726/978-3-653-05973-1

13. Цибанюк О. Управління системою фізичного виховання школярів на Буковині (друга половина XIX - початок XX століття): дис. ... канд. пед. наук. Івано-Франківськ, 2008. 265 с.

14. Дарійчук С. В. Тіловиховна та здоров'язберігаюча тематика соціал-демократичної преси Буковини початку ХХ ст.: мат. III всеукр. конф. // Соціально-гуманітарні науки та сучасні виклики. Дніпро: Дніпровський національний університет, 2018. С. 277-280.

15. Ячнюк І. Історичні етапи професійної підготовки вчителів фізичної культури на Буковині // Історичні, філософські, правові й кадрові проблеми фізичної культури. 2015. С. 23-26.

16. Гімнастично-пожарничий курс // Народна справа. Чернівці, 1908. Ч. 22-23. С. 9.

17. Запомоги для Сїчей // Громадянин. Чернівці, 1909. С. 4.

18. Курс пожарничо-гімнастичний «Союза Січей» на Буковині // Громадянин. С. 2.

19. Сїчові вісті // Громадянин. Чернівці, 1909. Ч. 21-22. С. 4.

20. Інститут післядипломної педагогічної освіти Чернівецької області: дати, події, постаті. 3 нагоди 75 -ліття від часу заснування. Чернівці, 2015. 276 с.

Received date 19.12.2019

Accepted date 24.01.2020

Published date 30.01.2020

Цибанюк Олександра Олександрівна, кандидат педагогічних наук, доцент, кафедра теорії та методи фізичного навчання та спорта, Чернівецький національний університет імені Юрія Федьковича, вул. Коцюбинського, 2, м. Чернівці, Україна, 58012

E-mail: molodost.cv@gmail.com 